Portland State University

PDXScholar

Fall 12-12-2013

\title{
Soil Development and Vegetation Response to Removal of a Small Dam, Lassen Volcanic National Park, California
}

Stephanie Kay Rohdy

Portland State University

Follow this and additional works at: https://pdxscholar.library.pdx.edu/open_access_etds

Part of the Environmental Monitoring Commons, and the Terrestrial and Aquatic Ecology Commons Let us know how access to this document benefits you.

Recommended Citation

Rohdy, Stephanie Kay, "Soil Development and Vegetation Response to Removal of a Small Dam, Lassen Volcanic National Park, California" (2013). Dissertations and Theses. Paper 1507.

https://doi.org/10.15760/etd.1513

This Thesis is brought to you for free and open access. It has been accepted for inclusion in Dissertations and Theses by an authorized administrator of PDXScholar. Please contact us if we can make this document more accessible: pdxscholar@pdx.edu. 
Soil Development and Vegetation Response to Removal of a Small Dam,

Lassen Volcanic National Park, California

by

Stephanie Kay Rohdy

A thesis submitted in partial fulfillment of the requirements for the degree of

\author{
Master of Science \\ in \\ Geography
}

Thesis Committee:

Martin Lafrenz, Chair

Barbara Brower

Sarah Eppley

Portland State University

2013 


\begin{abstract}
Dam removal is increasing as dams age, yet little is understood about the pedogenic response to dam removal. This study reports on the edaphic changes of reservoir sediments and vegetation cover one year following removal of a small earthen dam in Northern California. In August 2012, I sampled surface sediments from the former Dream Lake reservoir in Lassen Volcanic National Park, and compared their physical and chemical properties with soil samples from two reference sites. I also estimated percent cover of vegetation in the former reservoir and reference sites. My results show that the reservoir was under reduced conditions, as determined by gleyed soil color and a higher $\mathrm{pH}$ when compared to reference samples. In contrast to reservoirs on larger river systems which tend to be sinks for organic matter, Dream Lake showed a reduction in organic matter when compared to reference locations.

My results suggest reservoirs created by dams cannot be considered to have similar sediment properties, namely increases in organic material. Unlike other studies that found former impoundments invaded by non-native species, the former Dream Lake site has been colonized by native grasses, sedges, and rushes. This study documents the edaphic properties and vegetation response of a small reservoir one year after dam removal, and suggests a more thorough investigation of those properties prior to undertaking costly restoration of these highly dynamic systems.
\end{abstract}




\section{ACKNOWLEDGEMENTS}

I would like to thank Dr. Martin Lafrenz for his willingness and graciousness in becoming my advisor so late in this process, and providing the knowledge, insight, and guidance to make this project something to be proud of. Thank you to Dr. Barbara Brower for inspiring me to begin this journey in the first place, for listening to my numerous ideas for research, and helping me seize the opportunity in Lassen when it presented itself. Also, thank you to Sarah Eppley for her willingness to serve on my committee and answer so many of my questions about plants, statistics, and research design. Thank you to the Oregon Community Foundation, and the Department of Geography for providing funds to support my field research.

I would also like to recognize and thank Janet Coles, former vegetation ecologist at Lassen Volcanic National Park for making this project a reality, assisting with the permit process, and being willing to pull me out of the muck that we know and love as "the smelly mud pit." To my parents, thank you for your endless support and

encouragement, and providing motivational pep talks when needed. Finally, I would like to thank Scott, who has supported me through this journey, listened to my frustrations, shared in the excitement, and sat beside me on this rollercoaster that is graduate school smiling, with both hands in the air. 


\section{CONTENTS}

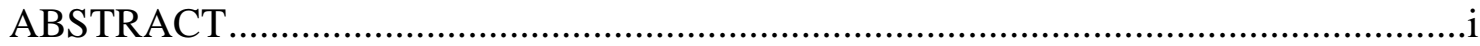

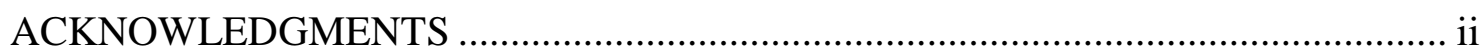

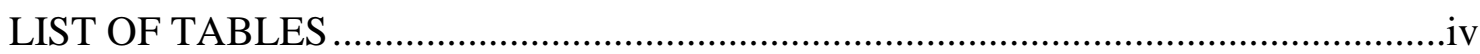

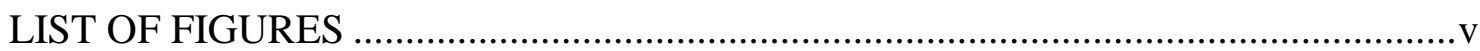

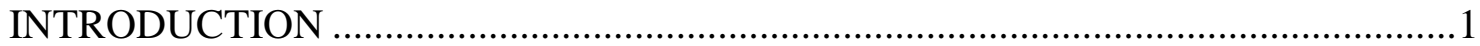

Dam Removal Research.................................................................... 3

Measuring Reservoir Soil Properties ........................................................

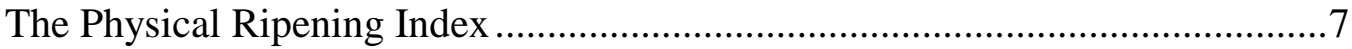

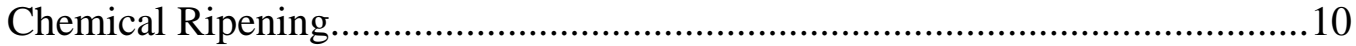

Historical Context .......................................................................... 11

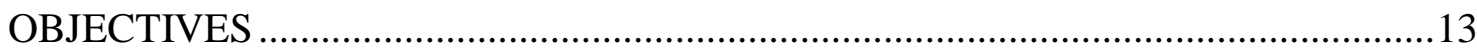

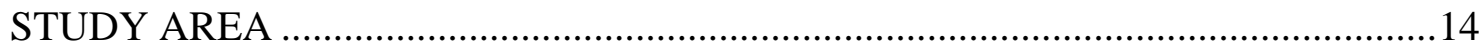

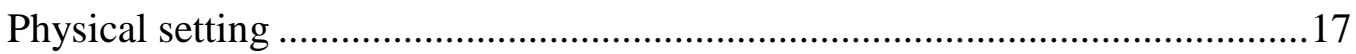

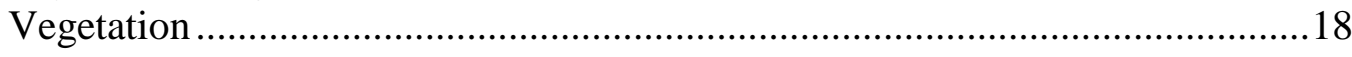

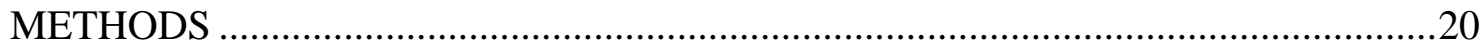

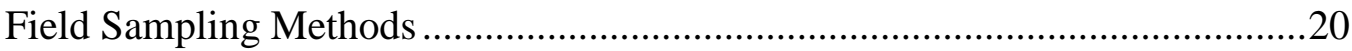

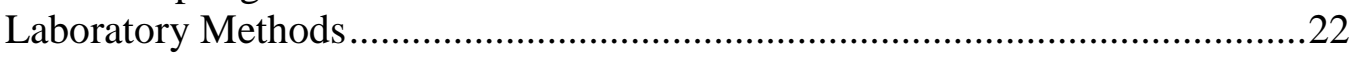

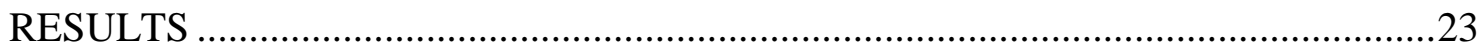

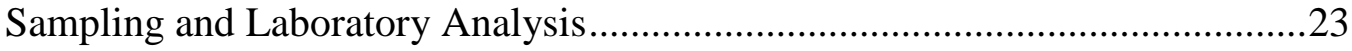

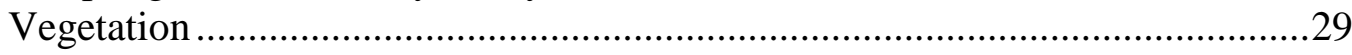

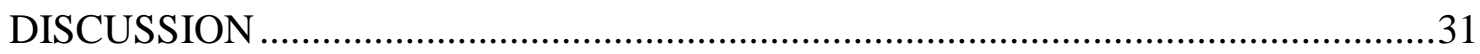

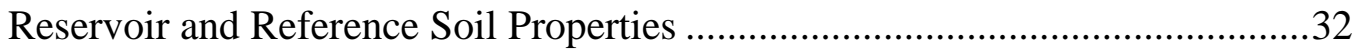

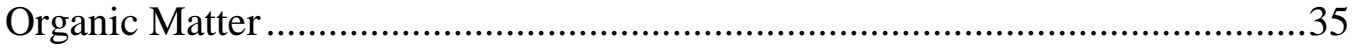

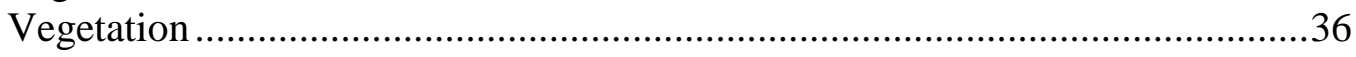

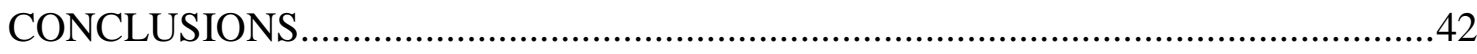

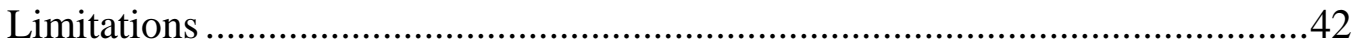

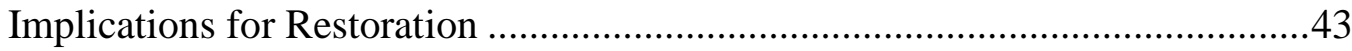

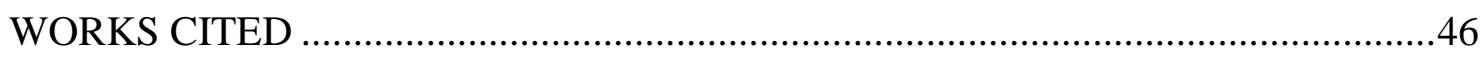




\section{LIST OF TABLES}

Table 1. Descriptive statistics for physical and chemical properties in reference and reservoir sites.

Table 2. Physical data for all samples including ripening index values $(n)$. Samples 1 and 2 from transects A-E are reference sites that sit outside the former reservoir; samples 3-5 are located within the boundary of the former reservoir

Table 3. Chemical property data for all samples.

Table 4. Percent canopy cover of all species observed at Dream Lake Reservoir and reference quadrats, and total species count for all locations.

Table 5. Common soil characteristics observed following dam removal in a large river system when compared with undisturbed reference soil, and soil characteristics from the Dream Lake reservoir compared to its reference soil 


\section{LIST OF FIGURES}

Figure 1. Examples of the physical characteristics of ripening. Left (a): cracking as a result of dehydration of exposed sediment. Right (b): Subsidence indicated by the isolation of sediment from the reservoir surface in the center of the reservoir.

Figure 2. Map of Lassen Volcanic National Park, and location of study area 16

Figure 3. Photo of Dream Lake Dam, following removal and leveling. Outflow channel in foreground was created by NPS during drawdown and draining of the lake in August of 2011 .....

Figure 4. Transect locations at Dream Lake Reservoir (A-E) and transect locations for the meadow site (REF A and REF B).

Figure 5. Box and whisker plots comparing mean values of soil properties between reservoir quadrats $(n=15)$ and reference quadrats $(n=16)$ sites. $\mathrm{pH}$ is compared by median values.

Figure 6. Left (a): Dream Lake immediately following dewatering, August 2011. Right (b): Dream Lake showing rapid plant growth within two months of exposure.

Figure 7. Rapid revegetation of Dream Lake, August 2012 .39 


\section{INTRODUCTION}

Since the $19^{\text {th }}$ century, more than 87,000 dams have been built in the U.S. (USACE 2013), restricting the flow of rivers in order to produce hydropower, create recreational opportunities, deliver water to thirsty communities, irrigate agriculture, and provide protection against floods (Pohl 2002). According to the advocacy group American Rivers, more than 925 dams have been removed across the U.S. in the last 100 years (American Rivers at http://www.americanrivers.org). Many dams are reaching the end of their structural lifespan, compelling managers to make costly repairs, retrofit, or remove the structures completely. When aging dams are removed, ecological restoration of the former reservoir surface sometimes follows.

My research focuses on removal of a small dam in northern California, and compares the soil characteristics and vegetation cover of the dewatered reservoir with undisturbed reference sites. There is little research on the soil conditions of former reservoirs following dam removal. The increased frequency of removals and subsequent restoration of former reservoir surfaces suggests the knowledge of soil and sediment characteristics can promote successful revegetation projects, and my results will assist in this effort.

The Society of Ecological Restoration (SER) defines ecological restoration as "the process of assisting the recovery of an ecosystem that has been degraded, damaged, or destroyed" (SER Primer 2004). The restoration of an ecosystem may include remediation, rehabilitation, or ecological engineering. There are two types of restoration that project managers often choose to employ depending on time, money, and desired outcomes. Passive restoration simply requires halting the activity that caused degradation 
of the ecosystem and allowing the system to recover naturally without further human interaction (Boone-Kauffman et al. 1997). In contrast, active restoration involves a purposeful manipulation of the ecosystem in the hope of spurring the system toward recovery. In the U.S., billions of dollars are spent each year on active restoration, with riparian areas receiving much of this attention (Bernhardt et al. 2005). For example, many active restoration projects attempt to stabilize stream banks with engineering materials or the planting of vegetation to improve in-stream habitat and to facilitate fish passage. The National Research Council (1992) defines riparian restoration as the reestablishment of pre-disturbance riparian functions and related chemical, biological, and physical processes. The goals of riparian projects often include the return of an ecosystem to a certain desired condition that mimics a nearby reference site, or to a condition that replicates a specific moment in time.

Restoration projects following dam removals aim to restore former reservoirs and stream channels to their pre-dam conditions, but a lack of historic ecological data makes the task difficult. Ecosystems are also in a constant state of flux, making it difficult to pinpoint one moment in time as a measure of success; this is particularly difficult in areas disturbed by dam building. A reference site can also be chosen and the success of the restoration project evaluated by how closely the restored area resembles the reference site plant communities and ecological function in the years following completion. Often, too little attention is paid to the chemical and physical processes involved in riparian restoration projects, and the bulk of project planning is centered on above ground biological processes. 


\section{Dam Removal Research}

Determining if the goals of a restoration project have been met is often hampered by the lack of long-term post-restoration monitoring. Funding for monitoring typically stops shortly after implementation leading to a deficiency in quantitative data reporting on the success, or failure, of restoration projects (Bernhardt et al. 2007). This is certainly the case with dam removal projects although a few studies have attempted to document vegetation development (Auble et al. 2007, Orr and Koenig 2006, Orr and Stanley 2006, Shafroth et al. 2002), channel response (Doyle, Stanley, and Harbor 2002, Doyle et al. 2005), and the hydrologic impacts of dam removal (Lenhart 2000).

Orr and Koenig (2006) studied vegetation establishment on exposed mudflats following two dam removals in Wisconsin. They actively planted native vegetation at two sites, and allowed other areas to recover naturally. None of the native species that had been planted were observed after four years of monitoring both the passive and active revegetation sites. They found that the seedbank at each site had ultimately contributed more species to the plant community over the four years of monitoring. The results of this study suggest that active restoration of vegetation in recently dewatered sediments may be a costly and futile practice.

Orr and Stanley (2006) used a space-for-time substitution to characterize plant communities in thirteen former reservoirs in Wisconsin. The amount of time the reservoirs had been dry ranged from six months to forty-six years. They found that colonization of recently de-watered reservoirs occurred quickly, but was extremely variable. Invasive species were common at all sites regardless of age. As the former reservoirs progressed from mesic to xeric conditions over time, aquatic plants showed 
reduced frequency. Their results documented how quickly a former impoundment can re-colonize, and what types of plant communities may emerge over time including the dominance of non-native species.

Wisconsin has been a leader in dam removal projects, with more than 100 dams removed since 1967 (WDNR 2013). The state's long history of dam removals has provided scientists and researchers with opportunities to study ecological responses of former reservoirs. Results and conclusions drawn from studies of vegetation response to dam removal have helped shape the planning and implementation of subsequent restoration projects. However, it is unclear how representative this research is to other geographic areas with different geology, landscape dynamics, flow regime, and vegetation types. Additionally, the bulk of research on the ecological response to dam removal has focused on vegetation establishment, with little investigation into soil characteristics and properties of the dewatered sediments even though these edaphic conditions must surely drive vegetation dynamics.

The largest, and perhaps most publicized, dam removal project in the country is located in Olympic National Park in Washington State. The planning process for the removal of two large dams on the Elwha River began in 1992, with the goal of improving stream habitat for native salmon (Duda, Freilich, and Schreiner 2008). The ecological impacts these dam removals will have on the river system and surrounding areas has been a focus of ongoing scientific research, including with respect to passive and active restoration techniques (Cook et al. 2011), seed bank viability and dispersal (Brown and Chenoweth 2008, Michel, Helfield, and Hooper 2011), and the probable response of fish populations (Pess et al. 2008). The lengthy planning process involved with the Elwha 
project provided time for scientists to collect baseline data before the dams were removed. Perhaps more importantly, the project provides researchers a unique opportunity to test models, predictions, and ecological theories about dam removal. However, these dams are still in the process of being removed, and the data is yet to be published. As such, my research represents some of the first completed vegetation analysis following dam removal in the Pacific Northwest.

Dam removal is a relatively new phenomenon, but the restoration of disturbed ecosystems has been occurring for decades. Restoration of former impoundments typically focuses on restoring a site to its pre-disturbance condition by reinforcing riverbanks, stabilizing channels, and planting vegetation. To date, few studies have focused on soil development following dam removal, though it has been suggested that soil and sediment deposits likely have significant impacts on restoration goals and ecosystem trajectories in newly exposed areas (Lenhart 2000, Shafroth et al. 2002, Doyle and Harbour 2003). Understanding soil development and properties following dam removal can assist managers in making more informed choices when faced with the restoration of disturbed soils and sediments.

\section{Measuring Reservoir Soil Properties}

Change in the nature and properties of soil and sediment immediately following dam removal has received little attention largely because scientists initially focused on the impacts of eroded reservoir sediment (Stanley et al. 2002), the evolution of stream channels in the former reservoir (Doyle, Stanley, and Harbor 2002), and initial vegetation conditions (Shafroth et al. 2002). Wells et al. (2008) did investigate the differences 
between reservoir-deposited sediment and buried substrate but did not document how the exposed sediment changed after dam removal. Currently, only one study has reported on soil development following dam removal (Lafrenz, Bean, and Uthman in press); this study found that several years following dam removal the dewatered surface sediments were physically similar to a reference soil but were much different with respect to chemical and biological properties.

The linkages between biological, hydrological, and soil/geomorphic conditions are what shape riparian function and structure (Boone-Kauffman et al. 1997). Riparian restoration projects must consider each of these components in order to restore ecological function. Most riparian restoration projects focus on actively planting native vegetation, and stabilizing and restoring historic stream channels. However, in order to completely restore hydrologic, geomorphic, and biological conditions, soil and sediment properties must also be considered. Dams and their subsequent removal present a highly dynamic and disturbed environment to managers seeking to restore a site to pre-dam conditions. A lack of data reporting on the stability and physical properties of newly dewatered sediments presents a knowledge gap for restoration practitioners that if filled, could lead to increased success of revegetation projects in reservoirs following dam removal.

We know that soil characteristics such as texture and $\mathrm{pH}$ are limiting factors to the types of vegetation that can establish in a given area (Laughlin and Abella 2007). For instance, riparian areas dominated by silt and clay soil types and shallow elevation gradients tend to be favored by rushes, sedges, and hydrophytic grasses, while woody shrubs favor riparian areas containing coarse, well-drained soils (Boone-Kauffman et al. 1997). Hence, the physical and chemical properties of a newly exposed reservoir surface 
following dam removal will have significant impact on the resulting plant communities that can establish there.

Almost immediately following the draining of a reservoir, physical and chemical changes occur in the exposed sediment, creating a highly variable environment that is little understood. Wells et al. (2008) investigated reservoir sediments and subsoils one year after a dam removal in southwestern Wisconsin. They found that surface sediments were relatively homogenous in both physical and chemical properties, but varied significantly from the soils below. Although they did not compare their dewatered sediment to a reference surface soil, which would have allowed for some estimate of soil change following dam removal, they did find that the properties of the dewatered sediment varied with distance from the dam. Thus, the water depth of the former reservoir may be a factor that influences vegetation dynamics dam removal.

\section{The Physical Ripening Index}

The term "ripening" was first coined in the early 1960's to describe the initial onset of soil pedogenesis following the dewatering of estuarine sediments by diking (Pons and Zonneveld, 1965). Specifically, ripening referred to "the initial soil formation processes that render a soft alluvial deposit or peat suitable for agricultural use" (Pons and Zonneveld, 1965). Ripening is described in three ways: physical, chemical, and biological.

Physical ripening refers to the dehydration of soil following dewatering, which occurs following the draining of a reservoir after dam removal. Dehydration of sediments is caused by evaporation of water from the soil surface after draining and by 
plant growth as roots begin transpiring water from the subsurface. The soil begins to shrink, crack, subside, and increase in permeability (Figure 1). Cracks like those depicted in Figure 1a often result from the sudden drainage of a subaquatic environment; they are rarely seen in areas of natural drainage. Water not only dehydrates vertically through the soil profile, but horizontally as well. The subsidence in diked estuaries is often attributed to dehydration as well as the oxidation of organic material once dewatering has occurred (Pons and Zonneveld 1965).
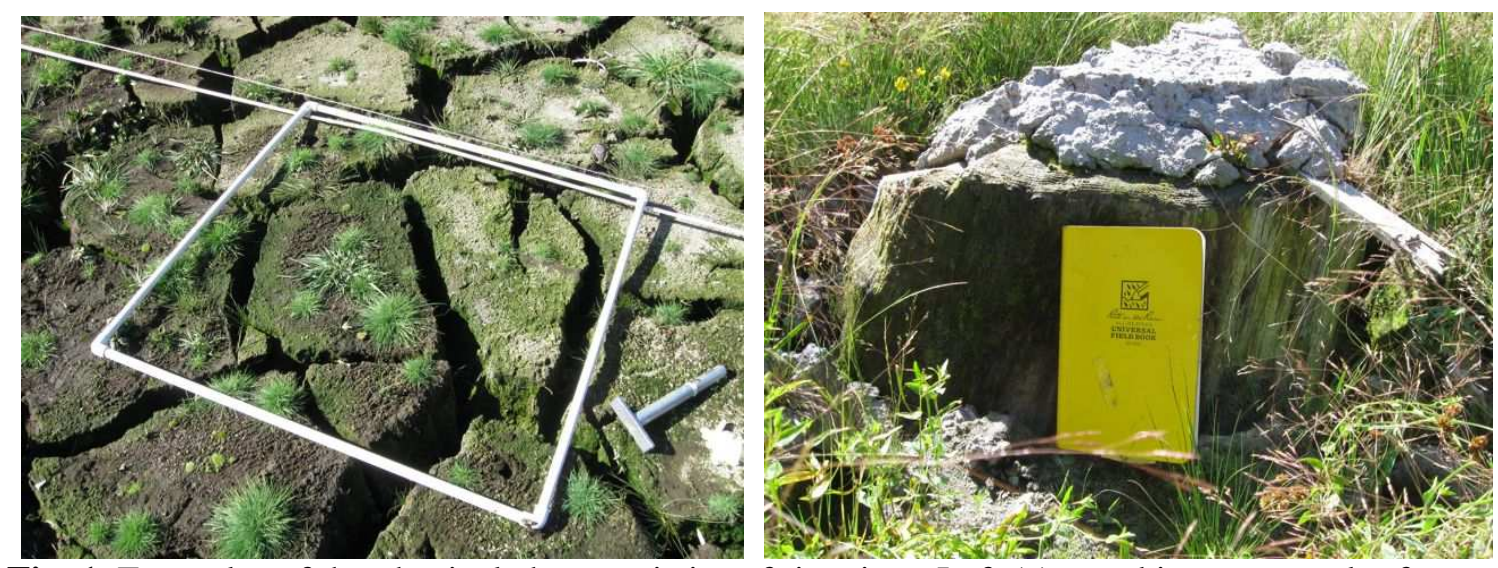

Fig. 1. Examples of the physical characteristics of ripening. Left (a): cracking as a result of dehydration of exposed sediment. Right (b): Subsidence indicated by the isolation of sediment from the reservoir surface in the center of the reservoir.

Physical ripening can be quantified using a ripening index originally suggested by Pons and Zonneveld (1965). The equation, which has been modified over time by Soil Survey Staff (1999) and Vermeulen et al. (2003), accounts for the soil water contained in all soil components including the water tightly bound to the colloidal fraction as well as the water more loosely bound to the sands and silts. The ripening index is calculated using the following formula:

$$
\mathrm{n}=(\mathrm{A}-0.2 \mathrm{R}) /(\mathrm{L}+3 \mathrm{H})
$$


In this equation, $n$ is the mass of water per unit mass of clay + organic matter, $\mathrm{A}$ is the water content of the soil per oven-dry weight, $\mathrm{R}$ is the percentage of sand + silt, $\mathrm{L}$ is the percentage of clay, and $\mathrm{H}$ is the percentage of organic matter. The $n$-value represents the amount of hygroscopic water bound to clay colloids and organic matter colloids. Silt and sand do not hold large amounts of water and dry quickly following dewatering, while water held by clay and organic matter decreases more slowly (Pons and Zonneveld 1965). As dewatered material dries, the $n$-value will decrease because the relative proportion of water in the silt + sand (the numerator value) is decreasing faster than the relative proportion of water in the clay + organic matter (the denominator value). A threshold $n$ value of 0.7 is used in the United States to determine if a soil will subside under a load after drainage (Soil Survey Staff 1999). Values below 0.7 are considered physically ripe and higher values indicate an unripe soil.

Though physical ripening values were originally used to determine the suitability of an area for agricultural use, the physical ripening index has been used to describe the beginnings of soil pedogenesis in dredge sediments (Vermeulen et al. 2005), marine environments (Kim et al. 1993), drained coastal areas (Pons and Zonneveld 1965), and drained wetlands (Drexler, de Fontaine, and Deverel 2009). Most of the research on physical ripening has taken place in the Netherlands (Vermeulen et al. 2003). This technique has been used only once to quantify changes in dewatered sediments following dam removal (Lafrenz, Bean, and Uthman in press). Hence, my research on soil properties and development immediately following dam removal will supplement the paucity of information currently available to scientists, resource managers, and policy makers charged with restoring reservoirs to their pre-dam conditions. 


\section{Chemical Ripening}

When oxygen is prevented from reaching and entering soil because of continuous saturation in a reservoir environment, reduced conditions develop and soils may become hydric (Vepraskas and Faulkner 2001). Hydric soils can be identified in the field by certain characteristics, such as gleyed color and relatively high $\mathrm{pH}$. Chemical ripening, or oxidation, is driven by oxygen entering the newly exposed surface sediments, but does not occur immediately upon drainage of the reservoir (Pons and Zonneveld 1965).

Oxidation-reduction (redox) reactions drive the availability of plant nutrients in soil (Vepraskas and Faulkner 2001). Oxidation reactions involve the loss of one or more electrons from an atom, and reduction reactions involve the gain of one or more electrons in the soil. In aerobic soils, oxygen is the first element to be reduced because it is readily available, and easily accepts electrons from other elements (Brady and Weil 1999). When oxygen is not available, as in an anaerobic environment, other chemical elements will begin to be reduced, such as nitrogen and iron. The soil is considered a reduced environment when these compounds begin to accept electrons (Vepraskas and Faulkner 2001).

Four conditions are needed in an anaerobic environment to support reducing reactions (Vepraskas and Faulkner 2001):

1. Oxygen must be excluded by continuous inundation or saturation of the soil.

2. Organic matter must be present for organisms to use for energy.

3. Microorganisms must be present.

4. Water must be slowly moving or stagnant.

If these four conditions are met, reduction reactions may occur. In a saturated 
environment, organic matter decomposes slowly and is the source of electrons used in reducing reactions. Therefore, organic material is necessary for reduction reactions to take place. Reduction also requires slow-moving or stagnant water because the constant churning created by faster flowing water introduces dissolved oxygen into the system, thus violating the first requirement for reduction reactions to take place.

\section{Historical Context of Study Area}

Dream Lake is located in the Warner Valley within Lassen Volcanic National Park (LAVO). The Warner Valley is home to the Drakesbad Guest Ranch, and has been a popular destination for tourists since the early 1900s. The Sifford family purchased the site in 1900, ranched the property, and expanded it into the popular vacation spot that it is today. The Sifford Family sold Drakesbad, which included the Dream Lake area, to the National Park Service (NPS) in 1958.

The Siffords were responsible for building the Dream Lake dam in 1932 (Hoke et al. 2005). The $3.5 \mathrm{~m}$ deep reservoir was created to offer fishing, boating, and swimming to guests of the ranch; it was even stocked with rainbow trout to appease visiting fishermen. A borrow pit from the adjacent upland forest was the source of the soil for the earthen dam. The dam had to be replaced or repaired twice during the Sifford's tenure as owners because of heavy snowfall and spring runoff. Beaver dams continually threatened the structural integrity of the dam and needed to be cleared each year to reduce the pressure being put on the structure (Hoke et al. 2005). Like many dams across the United States in the last decade, the Dream Lake dam reached the end of its structural life and was deemed unsafe. The Bureau of Reclamation gave the NPS two options: remove 
the dam or retrofit it to prolong its life. The NPS chose to remove the dam in order to reduce costs of the annual upkeep of the failing structure (Johnson et al. 2009).

Immediately after the dam was removed in 2011, I began monitoring ecosystem recovery. 


\section{OBJECTIVES}

The objective of my research is to understand the physical and chemical changes of soil and sediment in the former reservoir, one year after dam removal. I will compare physical and chemical properties of the reservoir soils with undisturbed reference soils.

Given what we know about fluvial processes and that reservoirs act as traps for sediment and organic material, I hypothesize the following.

1. The physical and chemical properties of sediment will differ from the soil properties at the reference location.

2. The sediment and vegetation in the Dream Lake reservoir will respond in a fashion similar to other dam removal sites described in the literature. Along with soil physical and chemical properties of the dewatered sediment, I also report on general plant community establishment at both sites. Identifying specific soil characteristics in this highly dynamic environment will allow restoration practitioners, scientists, and policy makers to make more informed decisions, improving the outcome of restoration projects following dam removal in the future. 


\section{STUDY AREA}

My research site is a 12,140 square meter mudflat formerly known as Dream Lake in Lassen Volcanic National Park, Northern California (Figure 2). The former reservoir is a part of the North Fork Feather River Watershed, and the water surface was at 1707 meters of elevation. The Dream Lake site is north of $2258 \mathrm{~m}$ Sifford Mountain, and approximately 30 vertical meters above the creek that runs through Warner Valley. The site is a short hike from the Drakesbad Lodge and lies between two geothermal areas in the park. From above and when full, Dream Lake appeared as triangular in shape; it was filled by four spring-fed tributaries entering from the east and south sides of the basin. The water from Dream Lake eventually made its way into Hot Springs Creek. The four main inputs entering the basin are perennial and are supplemented by an ephemeral north-flowing stream and one intermittent stream entering from the south shore.

Dream Lake was drained in August 2011, and the dam was removed in early October 2011. The dam was removed and leveled with a bulldozer and the soil returned to the original borrow pit. The remaining soil at the former dam location is heavily disturbed and was actively revegetated by NPS staff in October 2011 (Figure 3). The channels then incised through the sediment and organic material that had collected at the bottom of Dream Lake over the past 80 years. The soil was extremely unstable in heavily saturated locations; sediment and organic material was several feet deep in various places. The sediment that was not washed away during the draining of the reservoir created a blank canvas on which plants could establish. After eighty years of being inundated by water the reservoir sediment has generally been free of additional human disturbance since dewatering. 
The Dream Lake site and the slopes that surround Drakesbad Meadow consist of slope wetlands and wet meadows. These areas are characterized by groundwater reaching the land surface (springs) and running along steep to slight slopes. Typically, wet meadows and slope wetlands are only seasonally inundated with water, but the high water table and poorly draining soils allow retention of high levels of moisture throughout the year (Machtinger 2007). Historically, the water that flowed from the slopes surrounding Warner Valley drained into Drakesbad Meadow, which is a rare mountain fen. However, ditching and diversion of the water away from Drakesbad Meadow for livestock grazing has altered the hydrology and vegetation of the rare ecosystem in the valley. 
Lassen Volcanic National Park

Northern California
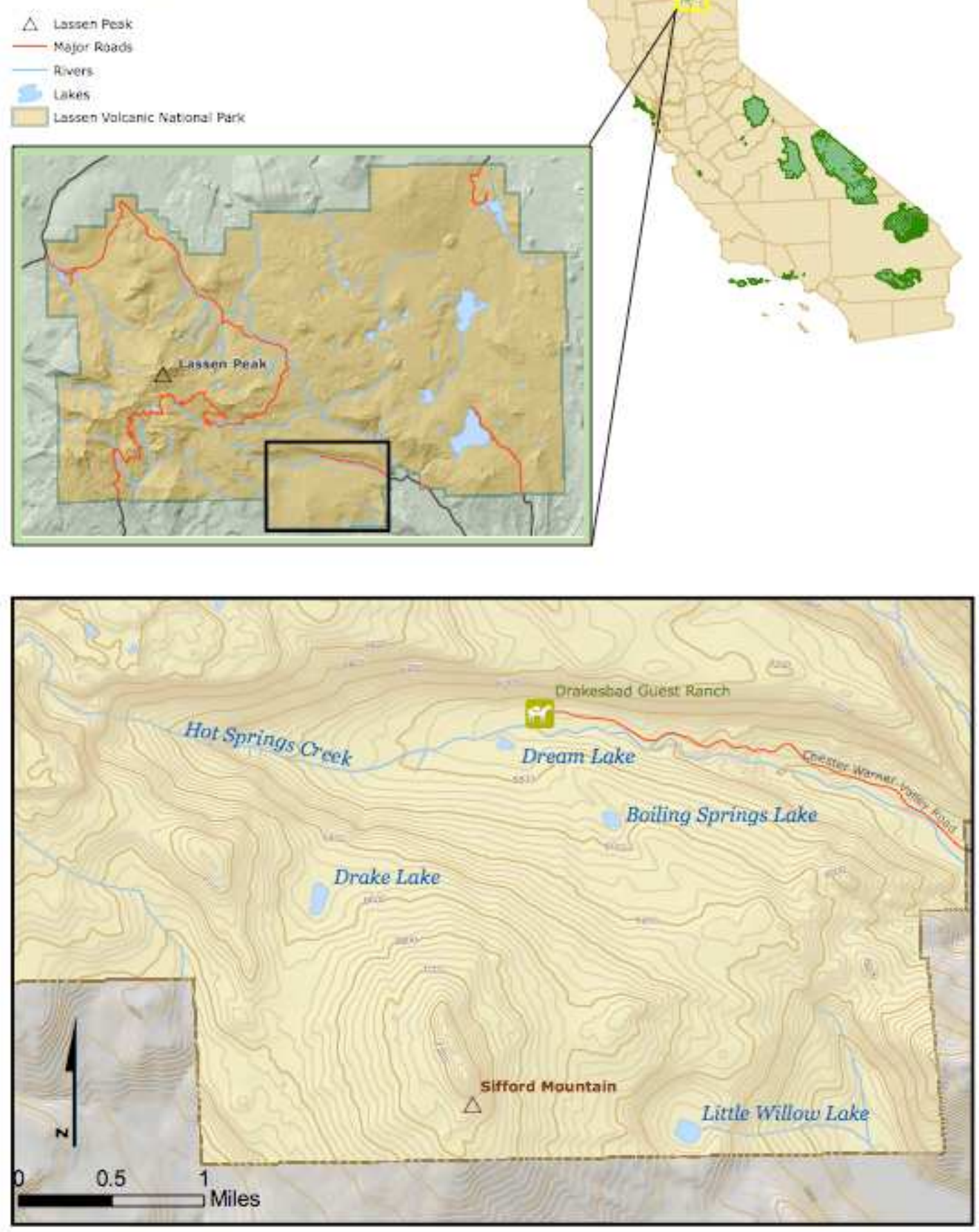

Fig. 2. Map of Lassen Volcanic National Park, and location of study area. 


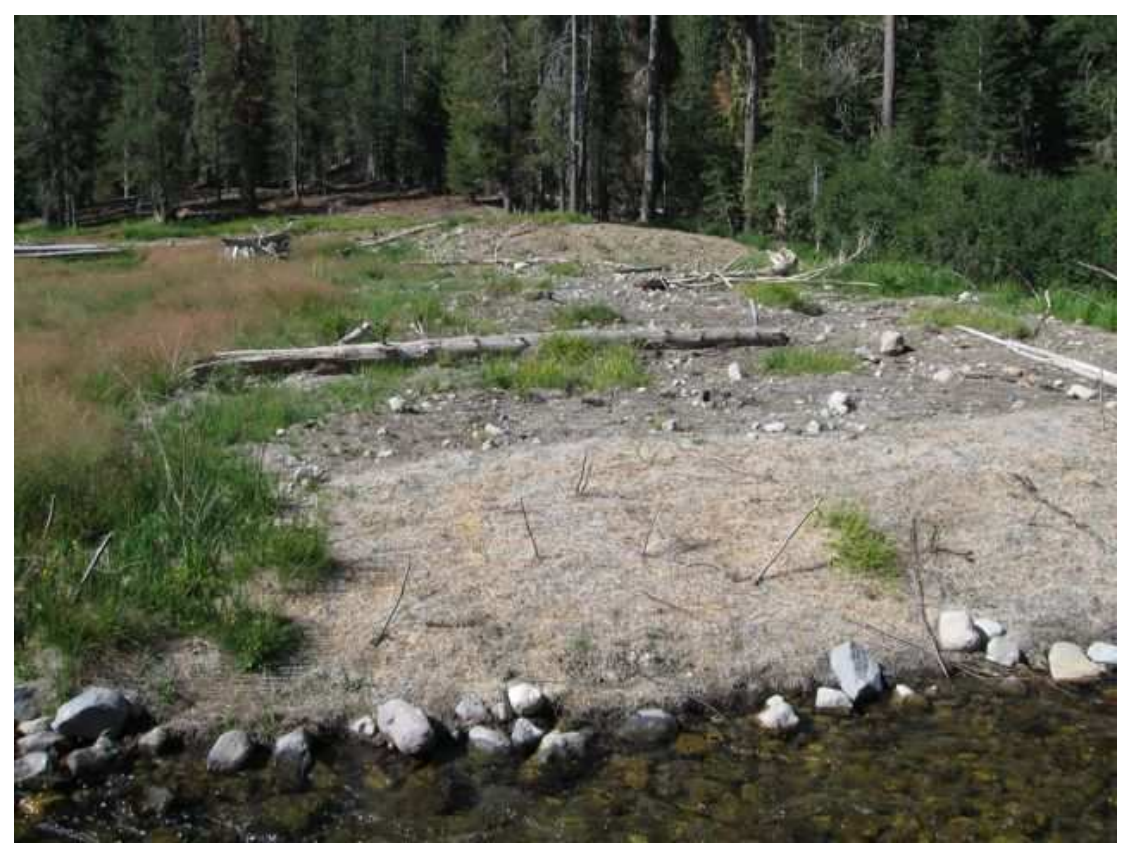

Fig. 3. Photo of Dream Lake Dam, following removal and leveling. Outflow channel in foreground was created by NPS during drawdown and draining of the lake in August of 2011.

Physical Setting

Lassen Volcanic National Park lies at the intersection of the Northern Sierra

Nevada and the Southern Cascades. The junction of these two ecoregions provides for an exceptional mix of flora in the park. Common features of these two areas include ponderosa pine and lodgepole forests, which are more susceptible to wildfire and need periodic low intensity fires to clear understory and prevent crown fire.

A continental climate regime dominates the LAVO complex. Extreme daily temperature shifts are not uncommon. Cold winters, warm summers and low relative humidity characterize the area. LAVO averages approximately 12 meters of snow per year with the winter's lowest temperatures occurring in the months of December and January. The average winter temperatures for nearby Chester, California range from -10 to -6 C. Summer daytime temperatures reach into the high 20 's $\mathrm{C}$ and average 
precipitation levels are less than $1.5 \mathrm{~cm}$ during the months of July and August (NCDC 2013). Subtle differences in park vegetation from west to east show that orographic lifting is a factor shaping ecosystems within the park.

Soils near the Dream Lake site are part of the Aquepts-Typic Petraquepts, bedrock-Aquic Haploxerands-Typic Petraquepts complex at 4-30\% slopes (NRCS 2012). The Aquepts are described as a poor drainage class with parent material derived from volcanic rock. The typical soil profile is characterized by a top layer $(0-5 \mathrm{~cm})$ of partially decomposed plant material, $5-15 \mathrm{~cm}$ of very bouldery mucky ashy sandy loam and remaining layers $(15-114 \mathrm{~cm})$ composed of extremely bouldery ashy sandy loam. Typic Petraquepts fall into the poor drainage class, with parent material also derived from volcanic rock. The profile ranges from partially decomposed plant material $(0-18 \mathrm{~cm})$ to very bouldery ashy loamy sand $(18-33 \mathrm{~cm})$, extremely bouldery ashy coarse sandy loam $(33-71 \mathrm{~cm})$, to extremely bouldery ashy loamy coarse sand at $71-89 \mathrm{~cm}$.

\section{Vegetation}

Before the 70m long, 2-5 m high dam at Dream Lake was built, the basin was a spring-fed riparian meadow surrounded by upland conifer forest. Today, the upland conifer forest is still present and comprised of white fir (Abies concolor), jeffrey (Pinus jeffreyi) and lodgepole pine (Pinus contorta), red fir (Abies magnifica), sugar pine (Pinus lambertiana), and incense cedar (Libocedrus decurrens). The understory is sparse and includes upland sedges, needlegrasses, huckleberry oak (Quercus vacciniifolia), hawkweed (Hieracium albiflorum), monkeyflower (Mimulus), spring beauty (Clyatonia lanceolota) and squirreltail (Hoke et al. 2005). In addition, invasive weeds present in the 
Warner Valley including cheat grass (Bromus tectorum), bull thistle (Cirsium Vulgare), reed canary grass (Phalaris arundinacea) and wooly mullein (Verbascum thapsus). Bull thistle is the invasive species that is in closest proximity to the site and poses the greatest threat to the restoration process. The shoreline surrounding the reservoir is dominated by sedges, which are common in the spring-fed slopes and riparian areas surrounding the Warner Valley. 


\section{METHODS}

\section{Field Methods}

To compare soils and vegetation between the reservoir and reference sites I placed a 110 meter baseline parallel to the south shore of the former reservoir with a compass bearing of 84 degrees from the west end of the baseline. I placed five, 50 meter transects with a compass bearing of 170 degrees perpendicular to the baseline at 22 meter intervals (Figure 4). Along each transect, two 1 x 1 meter quadrats were randomly placed outside the former reservoir within 10 meter intervals along the first 20 meters of measuring tape. Three 1 x 1 meter quadrats were randomly placed within the former reservoir along the remaining 30 meter measuring tape $(n=15)$. The first two quadrats along each transect at the reservoir site were analyzed as reference data $(n=10)$. For additional reference data, I placed a 55 meter baseline in a meadow west of the former reservoir (Figure 4). I placed two, 30 meter transects along the baseline at 20 meters and 40 meters. Along each transect in the meadow, I randomly placed three $1 \mathrm{x} 1$ meter quadrats within 10 meter intervals for a total of six additional reference quadrats. For statistical analysis, I combined reference samples from the meadow $(n=6)$ with reference samples from outside the reservoir $(n=10)$ for a total reference sample size of 16 . Random placements for each quadrat were determined using a random number generator.

I used the Daubenmire (1959) method of vegetation sampling to estimate canopy cover of vegetation in each quadrat. I also noted the time of day the vegetation survey began at each quadrat and noted any unique characteristics surrounding the quadrat. To record the locations of the baselines, transects, and quadrats I collected and then differentially corrected GPS positions using a Trimble Juno ST GPS unit. 
In order to characterize soil properties after the dam was removed, I collected soil samples from within each quadrat in the former reservoir and in all reference quadrats. To keep within NPS research permit requirements that limited the total volume of soil I could collect, I removed two, 2 x $10 \mathrm{~cm}$ soil cores from each quadrat and placed them in a sealed plastic bag. The composite samples were stored in a cooler and then frozen until laboratory analysis could be conducted. Being limited in the volume of allowed sample material, I chose to collect many surface samples rather then to dig a few deep soil pits; thus, my analysis is limited to the top $10 \mathrm{~cm}$ of the dewatered sediments but covers the maximum range of elevation in the former reservoir.

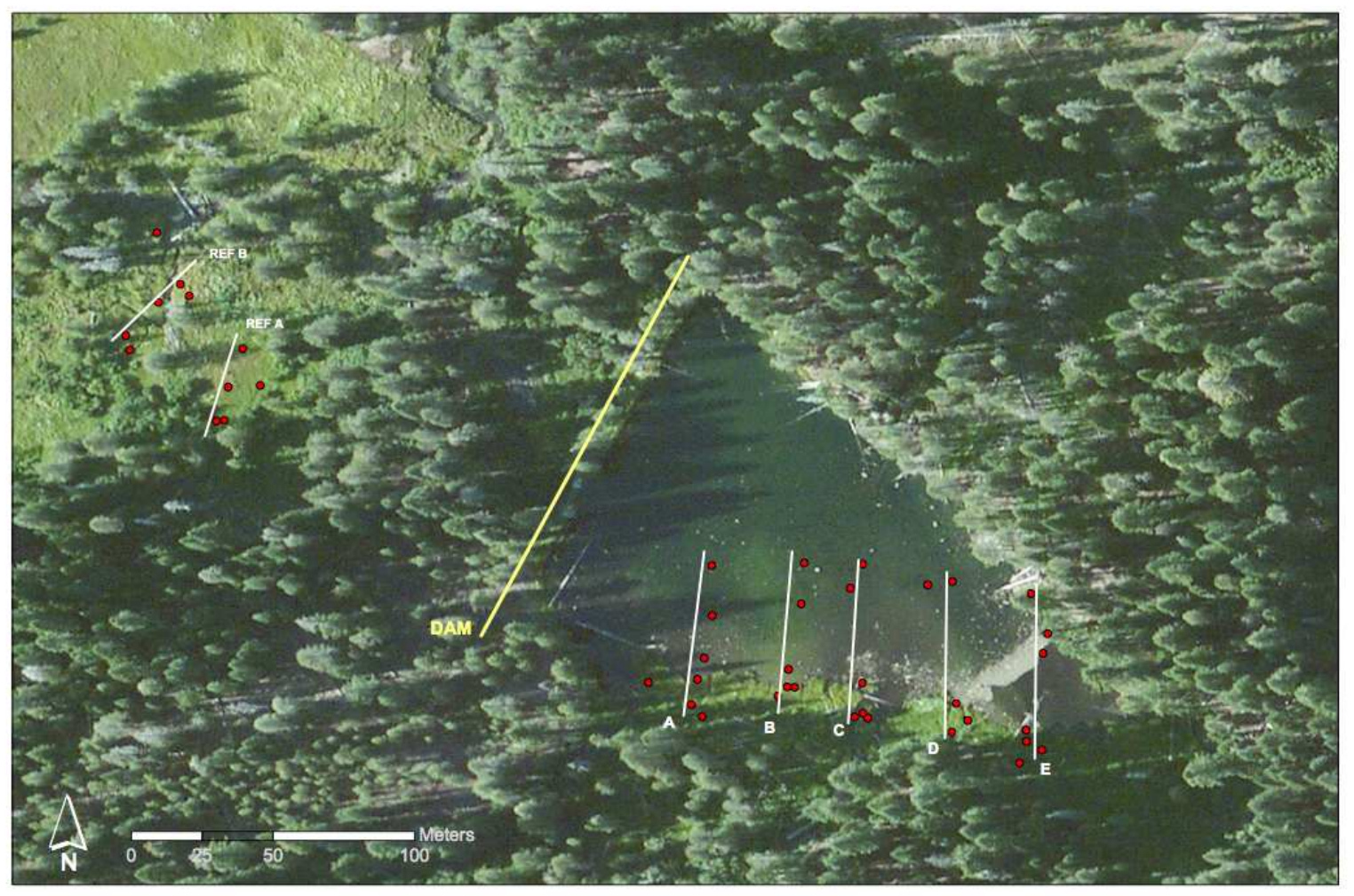

Fig. 4. Transect locations at Dream Lake Reservoir (A-E) and transect locations at the meadow site (REF A and REF B). 


\section{Laboratory Methods}

I conducted laboratory analysis to determine soil moisture, organic matter content, and texture of each soil sample, properties also needed to determine the physical ripening index $(n)$. I measured field moisture by drying each sample at $105^{\circ} \mathrm{C}$ using an Intell-Lab Moisture Analysis Balance. Organic matter content was measured by loss on ignition; a sub-sample of oven-dried soil was weighed and placed in a muffle furnace at $440^{\circ} \mathrm{C}$ for at least four hours or until there was less than $0.01 \mathrm{~g}$ change in weight (ASTM 2007c).

To determine the soil texture I measured five grams of air-dried soil, used a mortar and pestle to grind the sample and passed it through a 10-mesh sieve. $40 \mathrm{~mL}$ of $5 \%$ sodium hexametaphosphate solution was added to each sample to aid with dispersion, and samples were placed on a shaker overnight. I conducted a particle size analysis using the hydrometer method (Burt 2004), and spot-checked the results of eight samples using the modified pipette method (Gee and Or 2002).

To assess chemical ripening, I measured pH using a hand-held Hach H170G meter using the 1:1 $\mathrm{CaCl}$ method, which buffers for the seasonal effects of $\mathrm{pH}$ (Burt 2004). I used the Munsell color charts to determine the color of each air-dried sample and to compare reduced conditions between the reference samples and reservoir samples. My data were not normally distributed and required the use of the non-parametric MannWhitney test to determine the statistical significance of results from the reservoir when compared to the reference sites. 


\section{RESULTS}

\section{Sampling and Laboratory Analysis}

Field sampling took place over three days in August of 2012. In total, I collected thirty-one soil samples: six samples at an undisturbed meadow west of the reservoir (reference), ten samples at the reservoir from locations that were not continuously under water (reference), and fifteen samples were taken from the former lake bed. At each location, I collected basic information on vegetation cover to characterize emerging plant communities.

In order to assess the physical edaphic changes following the removal of the Dream Lake Dam, I measured organic material, soil moisture content, and determined the texture of each sample. The same variables were used to determine the physical ripening index of each sample. Mean organic matter was significantly higher in the reference sites $(n=16)$ than in the reservoir (Table 1 and Figure 5). Organic matter was also higher than the reservoir when compared with samples collected from the meadow location only. Mean field moisture was highest in reservoir samples, which is to be expected because of their recent release from year-round saturation, although the difference was not significant. Particle size analysis revealed reference soils were higher in sand content while reservoir soils had higher silt content on average (Table 1 and 2). Physical ripening calculations show that soils located in the reservoir were less physically ripe (high $n$ values) than soils in reference samples. 
Table 1. Descriptive statistics for physical and chemical properties in reference and reservoir sites.

\begin{tabular}{|c|c|c|c|c|c|c|}
\hline Location & Property & $\mathbf{n}$ & Mean & Median & Range & $\begin{array}{l}\text { Standard } \\
\text { Deviation }\end{array}$ \\
\hline \multicolumn{7}{|l|}{ All } \\
\hline \multirow[t]{6}{*}{ Reference } & Organic Material & 16 & 45 & 48 & 68 & 17 \\
\hline & \% Moisture & 16 & 67 & 70 & 34 & 12 \\
\hline & $\mathrm{pH}$ & 16 & $x$ & 5.2 & 2.2 & 0.6 \\
\hline & Ripening & 16 & 0.4 & 0.3 & 0.5 & 0.1 \\
\hline & $\%$ Sand & 16 & 61 & 63 & 67 & 21 \\
\hline & $\%$ Silt & 16 & 19 & 15 & 37 & 11 \\
\hline \multirow[t]{6}{*}{ Reservoir } & Organic Material & 15 & 35 & 34 & 25 & 6 \\
\hline & $\%$ Moisture & 15 & 72 & 76 & 49 & 15 \\
\hline & $\mathrm{pH}$ & 15 & $x$ & 5.4 & 1.3 & 0.3 \\
\hline & Ripening & 15 & 0.5 & 0.5 & 0.5 & 0.1 \\
\hline & $\%$ Sand & 15 & 42 & 37 & 69 & 21 \\
\hline & $\%$ Silt & 15 & 41 & 27 & 74 & 25 \\
\hline \multicolumn{7}{|l|}{ Reference } \\
\hline \multirow[t]{6}{*}{ Only } & Organic Material & 6 & 42 & 41 & 68 & 24 \\
\hline & $\%$ Moisture & 6 & 65 & 68 & 32 & 12 \\
\hline & $\mathrm{pH}$ & 6 & $x$ & 4.5 & 1.1 & 0.5 \\
\hline & Ripening & 6 & 0.4 & 0.3 & 0.4 & 0.1 \\
\hline & $\%$ Sand & 6 & 51 & 56 & 52 & 19 \\
\hline & $\%$ Silt & 6 & 24 & 20 & 35 & 13 \\
\hline
\end{tabular}



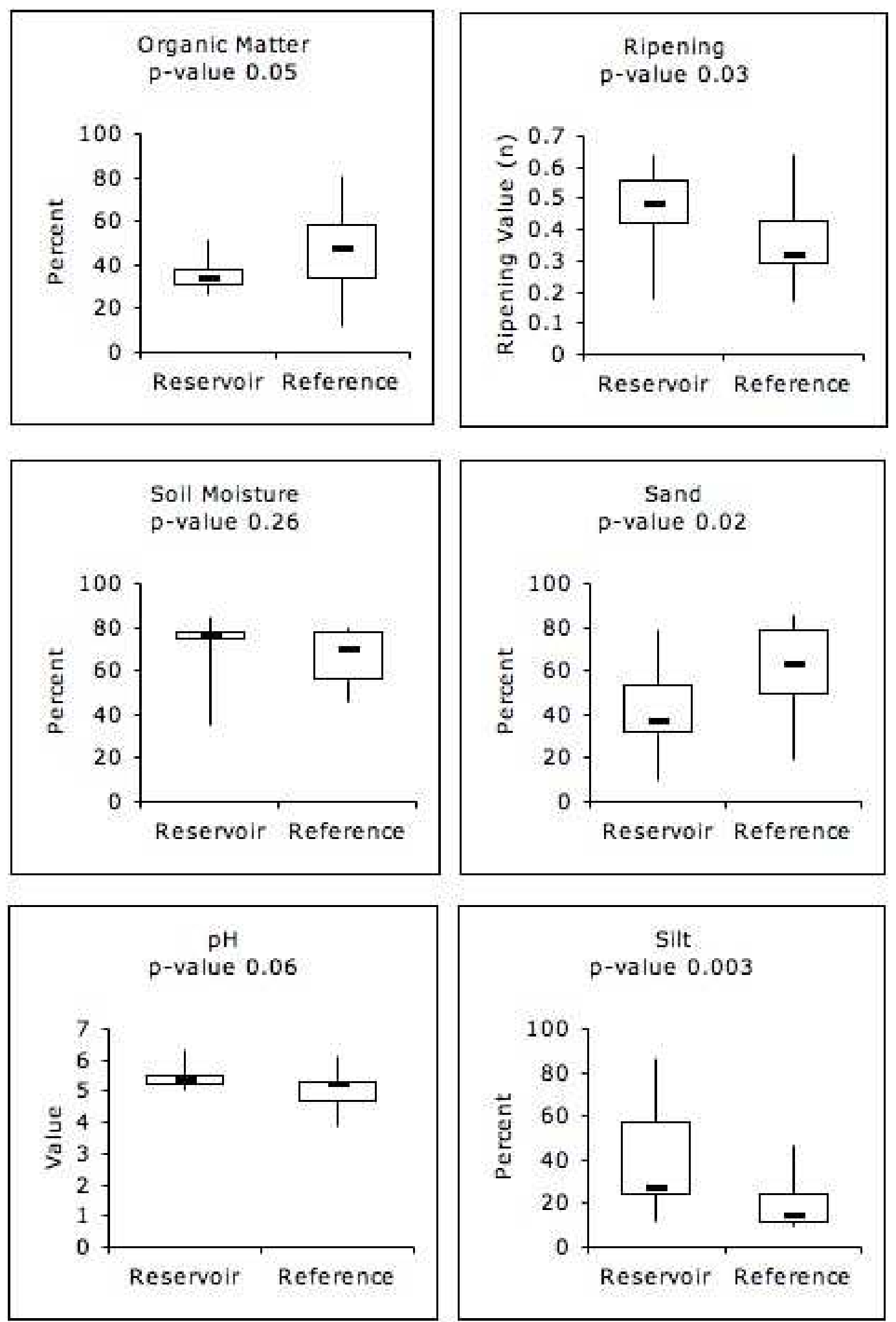

Fig. 5. Box and whisker plots comparing mean values of soil properties between reservoir $(n=15)$ and reference $(n=16)$ sites. $\mathrm{pH}$ is compared by median values. 
Table 2. Physical data for all samples including ripening index values $(n)$. Samples 1 and 2 from transects A-E are reference sites that sit outside the former reservoir; samples 3-5 are located within the boundary of the former reservoir.

\begin{tabular}{|c|c|c|c|c|c|c|c|c|}
\hline Transect & Sample \# & \% Sand & $\%$ Clay & \% Silt & Texture & $\begin{array}{c}\text { Soil } \\
\text { moisture } \\
\text { as } \%\end{array}$ & $\begin{array}{c}\text { Organic } \\
\text { Matter as } \\
\%\end{array}$ & n-value \\
\hline A & 1 & 64 & 2 & 34 & Sandy Loam & 46 & 57 & 0.2 \\
\hline A & 2 & 62 & 25 & 13 & Sandy Clay Loam & 57 & 34 & 0.3 \\
\hline A & 3 & 13 & 40 & 47 & Silty Clay & 37 & 32 & 0.2 \\
\hline A & 4 & 34 & 39 & 26 & Clay Loam & 76 & 34 & 0.5 \\
\hline A & 5 & 37 & 37 & 27 & Clay Loam & 75 & 27 & 0.5 \\
\hline B & 1 & 54 & 31 & 15 & Sandy Clay Loam & 70 & 37 & 0.4 \\
\hline B & 2 & 30 & 39 & 31 & Clay Loam & 52 & 59 & 0.2 \\
\hline B & 3 & 67 & 7 & 26 & Sandy Loam & 76 & 28 & 0.6 \\
\hline B & 4 & 13 & 3 & 84 & Silt & 78 & 34 & 0.6 \\
\hline B & 5 & 10 & 4 & 86 & Silt & 77 & 30 & 0.6 \\
\hline C & 1 & 85 & 5 & 10 & Loamy Sand & 78 & 62 & 0.3 \\
\hline C & 2 & 84 & 6 & 10 & Loamy Sand & 79 & 48 & 0.4 \\
\hline c & 3 & 50 & 2 & 48 & Sandy Loam & 78 & 51 & 0.4 \\
\hline c & 4 & 76 & 12 & 12 & Sandy Loam & 78 & 37 & 0.5 \\
\hline C & 5 & 36 & 42 & 22 & Clay & 76 & 38 & 0.4 \\
\hline D & 1 & 39 & 49 & 12 & Clay & 69 & 51 & 0.3 \\
\hline D & 2 & 84 & 0 & 16 & Loamy Sand & 80 & 36 & 0.5 \\
\hline D & 3 & 29 & 1 & 70 & Silt Loam & 80 & 32 & 0.6 \\
\hline D & 4 & 79 & 6 & 15 & Loamy Sand & 76 & 38 & 0.5 \\
\hline D & 5 & 46 & 2 & 52 & Silt Loam & 80 & 39 & 0.5 \\
\hline E & 1 & 83 & 8 & 10 & Loamy Sand & 77 & 61 & 0.3 \\
\hline $\mathrm{E}$ & 2 & 78 & 9 & 12 & Sandy Loam & 80 & 29 & 0.6 \\
\hline E & 3 & 57 & 18 & 25 & Sandy loam & 70 & 37 & 0.4 \\
\hline E & 4 & 42 & 41 & 18 & Clay & 84 & 36 & 0.5 \\
\hline E & 5 & 36 & 2 & 62 & Silt Loam & 35 & 26 & 0.2 \\
\hline REF A & 1 & 66 & 17 & 17 & Sandy Loam & 70 & 51 & 0.3 \\
\hline REF A & 2 & 53 & 19 & 27 & Sandy Loam & 69 & 48 & 0.3 \\
\hline REF A & 3 & 70 & 18 & 12 & Sandy Loam & 80 & 81 & 0.2 \\
\hline REF B & 1 & 58 & 25 & 17 & Sandy Clay Loam & 48 & 12 & 0.5 \\
\hline REF B & 2 & 40 & 13 & 47 & Loam & 67 & 24 & 0.6 \\
\hline REF B & 3 & 19 & 59 & 22 & Clay & 53 & 34 & 0.3 \\
\hline
\end{tabular}


To assess soil chemical changes following the removal of the Dream Lake Dam, I measured $\mathrm{pH}$ and determined color of each soil sample (Table 3). My results show more acid soils in the reference locations, with a median $\mathrm{pH}$ of 5.19 for all reference samples, and a median $\mathrm{pH}$ of 5.35 for reservoir soils, although the difference was not quite significant (Figure 5). However, when reporting data from the meadow site samples only, the results are significantly different. Soils in the meadow location have a median $\mathrm{pH}$ of 4.5, indicating much more acidic conditions than the reservoir soils. A more acidic $\mathrm{pH}$ in meadow soils indicates a more oxidized environment; the more basic $\mathrm{pH}$ levels in the reservoir samples indicate a more reduced environment that is chemically unripe. Soils in the reservoir also exhibited a more gleyed color (e.g., 2.5Y) when compared to reference soils (7.5YR), which is also indicative of reduced conditions. 
Table 3. Chemical property data for all samples.

\begin{tabular}{|c|c|c|c|c|c|}
\hline Transect & Sample \# & Munsell Code & Dry color & $\mathrm{pH} \mathrm{CaCl}$ & $\begin{array}{c}\text { Organic } \\
\text { Matter as \% }\end{array}$ \\
\hline$A$ & 1 & $7.5 Y R 3 / 2$ & Dark Brown & 5.0 & 57 \\
\hline$A$ & 2 & 10YR $3 / 2$ & Very Dark Grayish Brown & 5.3 & 34 \\
\hline$A$ & 3 & $2.5 Y 6 / 2$ & Light Brownish Gray & 5.3 & 32 \\
\hline$A$ & 4 & 10YR $5 / 2$ & Grayish Brown & 5.4 & 34 \\
\hline$A$ & 5 & $2.5 Y 6 / 2$ & Light Brownish Gray & 5.5 & 27 \\
\hline B & 1 & $7.5 Y R 3 / 3$ & Dark Brown & 5.1 & 37 \\
\hline B & 2 & $7.5 Y R \quad 4 / 2$ & Brown & 5.4 & 59 \\
\hline B & 3 & $2.5 Y 6 / 2$ & Light Brownish Gray & 5.0 & 28 \\
\hline B & 4 & $2.5 Y 6 / 2$ & Light Brownish Gray & 5.5 & 34 \\
\hline B & 5 & $2.5 Y 6 / 2$ & Light Brownish Gray & 6.3 & 30 \\
\hline C & 1 & 10YR $4 / 2$ & Dark Grayish Brown & 6.1 & 62 \\
\hline C & 2 & $2.5 Y R$ 4/1 & Dark Gray & 5.9 & 48 \\
\hline C & 3 & 10YR 5/1 & Gray & 5.4 & 51 \\
\hline C & 4 & 10YR 5/2 & Grayish Brown & 5.0 & 37 \\
\hline C & 5 & 10YR $5 / 2$ & Grayish Brown & 5.3 & 38 \\
\hline$D$ & 1 & 7.5YR $2.5 / 2$ & Brown & 5.3 & 51 \\
\hline$D$ & 2 & $2.5 Y 6 / 2$ & Light Brownish Gray & 5.3 & 36 \\
\hline$D$ & 3 & $2.5 Y 6 / 2$ & Light Brownish Gray & 5.2 & 32 \\
\hline$D$ & 4 & $2.5 Y 5 / 2$ & Grayish Brown & 5.1 & 38 \\
\hline $\mathrm{D}$ & 5 & 10 YR 4/1 & Dark Gray & 5.5 & 39 \\
\hline$E$ & 1 & $7.5 Y R 3 / 2$ & Dark Brown & 5.3 & 61 \\
\hline $\mathrm{E}$ & 2 & $2.5 Y 6 / 2$ & Light Brownish Gray & 5.5 & 29 \\
\hline $\mathrm{E}$ & 3 & 7.5YR 4/1 & Dark Gray & 5.3 & 37 \\
\hline $\mathrm{E}$ & 4 & $2.5 Y 6 / 1$ & Gray & 5.8 & 36 \\
\hline$E$ & 5 & $2.5 Y 6 / 2$ & Light Brownish Gray & 5.5 & 26 \\
\hline REF A & 1 & $7.5 Y R \quad 4 / 2$ & Brown & 5.0 & 51 \\
\hline REF A & 2 & $7.5 Y R \quad 4 / 2$ & Brown & 4.5 & 48 \\
\hline REF A & 3 & $7.5 Y R 3 / 2$ & Dark Brown & 4.5 & 81 \\
\hline REF B & 1 & 5YR 5/2 & Reddish Gray & 3.9 & 12 \\
\hline REF B & 2 & 5YR 4/2 & Dark Reddish Gray & 3.9 & 24 \\
\hline REF B & 3 & $5 Y R 4 / 2$ & Dark Reddish Gray & 4.8 & 34 \\
\hline
\end{tabular}




\section{Vegetation}

One year following dewatering, native perennial graminoids and herbs dominated the vegetation in the former reservoir. Juncus and Agrostis species occurred most frequently across the basin, while Carex species were most abundant in reference quadrats (Table 4). Of the plants that could be identified to species level, four were facultative wetland plants and one plant was an obligate wetland species.

Species richness between the reservoir and reference quadrats adjacent to the reservoir was identical, with twenty-three different species found in each, though several species found in the reservoir were not observed in the reservoir reference quadrats (Table 4). Species richness declined dramatically in the meadow quadrats, where only thirteen individual species were observed. More species in the meadow area overlapped with the reservoir reference quadrats than the reservoir quadrats.

The reference areas were dominated by Carex sp., but Carex occurred rarely in the reservoir. Carex species cover approximately 5\% of the dewatered area at Dream Lake, and account for $98 \%$ of cover at the meadow location. Carex also dominated the reference quadrats $(78 \%)$ sampled immediately outside of the reservoir. As evidenced by the increase in bare ground coverage, overall density of plant cover decreased with distance from the shore and along the soil moisture gradient. For example, bare ground was recorded at only two of the ten reference quadrats at the reservoir, A2 and E2 (Table 4). Sample A2 contained $57 \%$ soil moisture and E2 contained $80 \%$ moisture (Table 2). At quadrat A4 (soil moisture 76\%) bare ground coverage totaled 40\%. At quadrat E4 (soil moisture $84 \%$ ) bare ground coverage totaled $75 \%$. 
Table 4. Percent canopy cover of all species observed at Dream Lake Reservoir and reference quadrats, and total species count for all locations.

\begin{tabular}{|c|c|c|c|c|}
\hline Percent Cover & $\begin{array}{c}\text { Reservoir } \\
\text { Reference } \\
\text { Quadrats }\end{array}$ & Reservoir & $\begin{array}{c}\text { West } \\
\text { Reference } \\
\text { Area }\end{array}$ & $\begin{array}{l}\text { Wetland } \\
\text { Indicator }\end{array}$ \\
\hline Agrostis sp. & 12 & 61 & $<1$ & FACW \\
\hline Bare Ground & 2 & 23 & 3 & \\
\hline Carex sp 1 & 58 & & 98 & \\
\hline Carex sp 2 & 20 & & & \\
\hline Carex sp 3 & & 5 & & \\
\hline Cirsium vulgare & & $<1$ & & \\
\hline Epilobium sp. & 8 & 10 & & FACW \\
\hline Equisetum arvense & 5 & & $<1$ & FAC \\
\hline Flower 1 & $<1$ & & 1 & \\
\hline Grass 1 & $<1$ & & & \\
\hline Grass 2 & 3 & 11 & $<1$ & \\
\hline Grass 3 & 2 & 25 & & \\
\hline Grass 4 & & & 8 & \\
\hline Hordeum brachyantherum & $<1$ & 5 & & FACW \\
\hline Juncus sp. 1 & & 20 & & \\
\hline Juncus sp. 2 & & 5 & & \\
\hline Juncus sp. 3 & 1 & 33 & & \\
\hline Liverwort 1 & & 3 & & \\
\hline Logs & & 10 & 3 & \\
\hline $\begin{array}{l}\text { Lupinus polyphyllus Lindl. } \\
\text { var. burkei }\end{array}$ & 10 & & 5 & FACW \\
\hline Mimulus primuloides & 9 & 4 & & OBL \\
\hline Mimulus sp. 1 & 1 & 12 & & \\
\hline Ranunculus alismifolius & 3 & & & FACW \\
\hline Senecio triangularis & $<1$ & $<1$ & & FACW \\
\hline Unknown 1 & 7 & 2 & 1 & \\
\hline Unknown 2 & & $<1$ & & \\
\hline Unknown 3 & & $<1$ & & \\
\hline Unknown 4 & $<1$ & 20 & & \\
\hline Unknown 5 & 8 & & & \\
\hline Unknown 6 & $<1$ & 33 & & \\
\hline Unknown 7 & 2 & & & \\
\hline Unknown 8 & & $<1$ & & \\
\hline Unknown 9 & & 11 & & \\
\hline Unknown 10 & $<1$ & & & \\
\hline Unknown 11 & & & $<1$ & \\
\hline Unknown 12 & & & 3 & \\
\hline Unknown 13 & & & 3 & \\
\hline Total Species Count & 23 & 23 & 13 & \\
\hline
\end{tabular}




\section{DISCUSSION}

In this study, I examined the differences in edaphic conditions between an undisturbed reference meadow and a former reservoir that had recently been exposed by dam removal. The latter was inundated with water for more than eighty years by an earthen dam built to provide recreation opportunities for vacationers. The reservoir was drained in August 2011 and the sediment had been exposed for one year. I hypothesized that there would be significant differences between soil collected from the reservoir and reference soil, and that the edaphic response to dam removal at Dream Lake would progress in the same manner as in larger river systems where dams have been removed. With the first hypothesis, there were some significant differences between soils including percentages of sand, silt, and organic matter, as well as ripening value (Figure 5), but other variables were not different from the reference condition. However, with respect to the second hypothesis I found surprising differences in the response of this drained reservoir as compared to what has been found in other dam removal studies (Table 5).

\begin{tabular}{lcc}
\hline Soil Property & River & Wetland - Dream Lake \\
\hline Texture & Finer & Variable \\
Soil Moisture & Higher & Similar \\
$\mathrm{pH}$ & Higher & Higher \\
Nutrients & Higher & Lower \\
Organic Matter & Higher & Lower \\
\hline
\end{tabular}

Table 5. Common soil characteristics observed following dam removal in a large river system when compared with undisturbed reference soil, and soil characteristics from the Dream Lake reservoir compared to its reference soil. 


\section{Reservoir and Reference Soil Properties}

The input velocity of a river or stream is dramatically slowed as the water enters a reservoir. Sediment being carried by the faster moving water will drop out of suspension according to particle size, with heavier sediments falling farther away from the dam, and finer particles being deposited as they near the structure (Snyder et al. 2004, Wells et al. 2008).

Dream Lake reservoir soils show this spatial pattern, with a few anomalies. Transect A was closest to the dam and had the highest percentages of clay, with the three reservoir samples averaging $39 \%$. In contrast transect $\mathrm{D}$, which was farther away from the dam, averaged $4 \%$ clay among the three reservoir samples. Percentages of sand for these two transects also followed this pattern averaging $79 \%$ sand for reservoir samples at transect $\mathrm{D}$, and $28 \%$ sand at transect $\mathrm{A}$.

The number of inputs into the basin could explain the higher sand contents found in some of the samples. Unlike larger river systems that have been dammed with only one input stream, Dream Lake is a collection of smaller inputs that could distribute larger soil particles more widely across the basin. For example, sample $\mathrm{C} 3$ and $\mathrm{C} 4$ are adjacent to the larger north flowing inputs and have sand contents of 50\% and 76\% respectively. Reservoir samples for transect C and D show similar patterns in sand content. Sand content for samples C4 and D4 are much higher than their surrounding samples. Both of these locations lie at the mouth of the only east-west running stream into the basin. Before drainage and subsequent channel incision through the sediment, the flow of the river and drop in velocity may have deposited sandy sediment in line with locations C4 and D4. However, the dewatering process itself can mobilize finer sediments that have 
settled over time, exposing coarse sediment where fine sediment would be expected (Doyle et al. 2005, Wells et al. 2008).

After one year of exposure following dam removal, most of the sediment in the Dream Lake basin is physically ripe, or nearly ripened, but has not chemically ripened. These results are consistent with the results of Lafrenz, Bean, and Uthman (in press) who report that physical ripening three years after dam removal occurred quickly and to a depth of $1.1 \mathrm{~m}$ on upstream terraces left isolated by dam removal. Dream Lake is a smaller reservoir with a much different hydrology, and has been exposed for a shorter period, but it is showing signs of a similar ripening trajectory. When compared with reference sites, basin soils have higher $n$-values indicating that the basin soils that have been saturated are in the process of dehydrating and physically ripening. Soil moisture rates from the reservoir range from $34-84 \%$, compared to the reference meadow, where moisture ranges from $48-80 \%$.

Soils in reference sites provide a benchmark for comparing ripening index values to reservoir soils. One pair of reference samples is worthy of note. Reference locations E1 and E2 share similar particle sizes and soil moisture content, but E1 (n-value 0.3) appears to be more physically ripe than E2 (n-value 0.6$)$. When soils with similar field moisture and sand content are compared, the soil with higher colloidal material (clay and/or organic matter) will have the lower n-value and appear more physically ripe. Such is the case with reference sites E1 and E2.

My results show that reduced soil conditions exist in the reservoir, as indicated by the gleyed colors of samples taken from the basin. The difference in color is most prevalent when reservoir samples are compared with samples from the meadow location, 
which ranged from brown to dark brown and even dark reddish. Unlike the reservoir, the meadow location has not been inundated with water, resulting in continued chemical ripening represented by deeper, less muted soil colors.

The $\mathrm{pH}$ of the reservoir sediment was higher than the reference samples, which is consistent with reduced conditions (Vepraskas and Faulkner 2001). The process of reduction produces water and removes $\mathrm{H}+$ ions from solution, increasing the $\mathrm{pH}$ of soil and making it more alkaline (McBride 1994). Samples that were taken in a zone where water may have occasionally receded show colors more consistent with fluctuating water levels, i.e. light brownish gray. The difference in color could also be a product of organic matter staining, because these shore-like locations have higher amounts of organic matter than locations toward the center of the reservoir. The higher $\mathrm{pH}$ levels and more muted colors within the former reservoir denote that the sediments may not have physically ripened to a point where chemical ripening may begin.

Although the soil exhibits properties that suggest an anaerobic environment and reduced conditions, I expected that $\mathrm{pH}$ values would be higher. The Dream Lake soils were submerged for over eighty years. However, the various stream inputs of the basin combined with its relatively shallow depth may have supplied the soil with enough diffusible oxygen to prevent year-round reduction of elements. Therefore, unlike the anoxic hypolimnion layer found in deep reservoirs, the $\mathrm{pH}$ levels at the base of Dream Lake may have remained closer to their pre-dam levels because oxidation was able to occur intermittently. 


\section{Organic Matter}

Dams not only trap sediment, but also organic matter. Allochthonous inputs of organic material are carried by rivers and streams from upstream sources and sink to reservoir bottoms. Anaerobic conditions, like those in reservoirs, slow the decomposition of organic matter typically causing significant contrasts between reservoir soil and upland soil. Organic matter in the Dream Lake reservoir actually decreased when compared to the reference samples (Table 1), showing a significant difference of $p=0.05$ (Figure 5).

Dream Lake is surrounded by hydric soils; hence, the reservoir was likely more characteristic of a wetland area before the dam was built in contrast to larger river systems where the dam floods the uplands. Wetlands are high in organic matter because near constant saturation and high water tables slow the decomposition of organic material. Segini et al. (2010) compared the humification process of a seasonally flooded wetland and a permanently flooded wetland in the Andes. They found that the most important factor involved in the rate of humification was the presence of water. The permanently flooded wetland showed relatively lower humification rates when compared to the seasonally flooded wetland.

The levels of organic material in the reference soil at Dream Lake follow our expectation for wetland soils, with organic matter content averaging $45 \%$. Organic matter levels in the reservoir averaged 35\%. Lafrenz, Bean, and Uthman (in press) examined reservoir soils on abandoned terraces after the Marmot Dam removal in Oregon and found that organic matter was highest in the footslope position nearest the river at both upstream and downstream locations. The difference between these two studies could be related to the size of the river system that was dammed, the type of ecosystem 
being dammed, and the difference between autochthonous and allochthonous inputs of organic material.

The Dream Lake streams are small, and may not have been strong enough to be a constant source of allochthonous organic material to the system. Therefore, organic material would have had to been supplied in situ, including aquatic or terrestrial plants growing in or near the reservoir and dying off seasonally, in order to supply new organic material. The reservoir was too deep to support aquatic vegetation, and complete saturation during the growing season never allowed for the growth of new plants, except in the fluctuating shoreline areas surrounding the lake. Temporarily flooded wetlands are only saturated for a short time during year, allowing for high net primary productivity that ultimately contributes to the amount of organic material in a soil from year to year (NRCS 2007). Therefore, we should expect that the amount of organic material would be higher in the fluctuating zones of the lake and lower in the middle of the lake, where water levels never recede. The differences in organic matter between reference soils and reservoir soils may also be playing a role in the emerging plant communities within the reservoir.

\section{Vegetation}

Within three months after draining, the Dream Lake basin had a number of plants growing (Figure 6). Rapid vegetation growth in newly exposed sediment following a dewatering event is not uncommon (Shafroth et al. 2002, Orr and Koenig 2006, Orr and Stanley 2006, Auble et al. 2007). Additionally, studies of drained and abandoned beaver ponds have also reported prompt colonization of sediments with sedges and grasses (Neff 
1957, Butler and Malanson 2005, Hay 2010). The study by Orr and Stanley (2006) suggests that the timing of reservoir drawdown may play a critical role in determining initial plant establishment. For example, if dewatering occurs in mid-late summer, plants that surround the reservoir may contribute seed to the newly exposed mudflat, thus preparing for late fall growth or quick establishment in the following growing season.
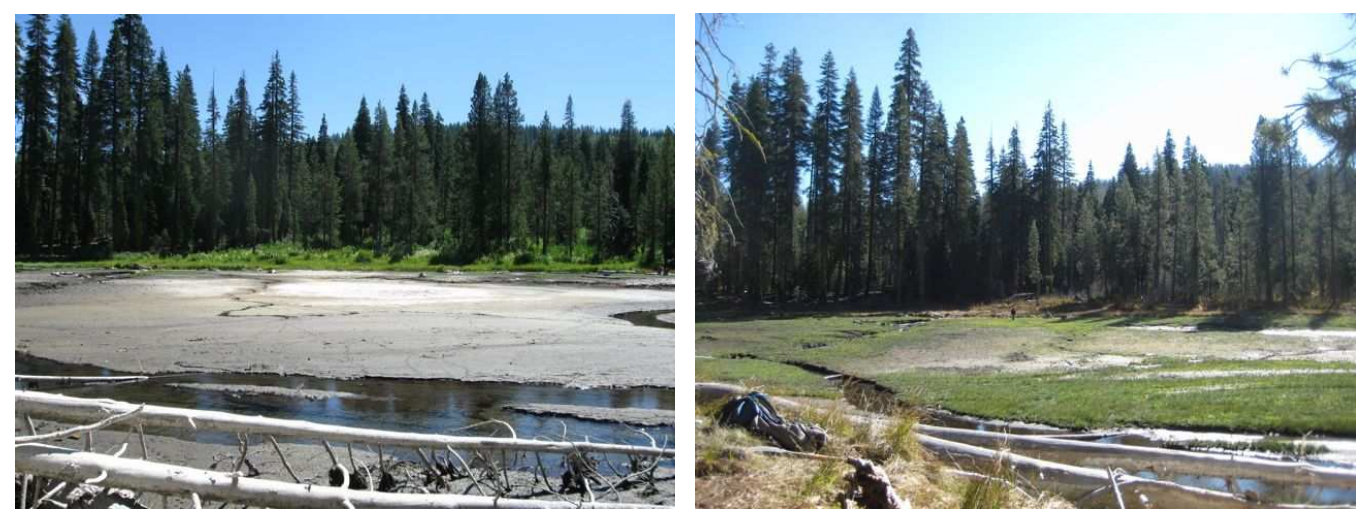

Fig. 6. Left (a): Dream Lake immediately following dewatering, August 2011. Right (b): Dream Lake showing rapid plant growth within two months of exposure.

By the time of this study in August 2012, the Dream Lake basin was lush with grasses, sedges, and herbaceous plants (Figure 7). Overall species richness in the basin was equivalent to the reference sites immediately outside the basin, and actually greater than the isolated western reference location. It is possible that the close proximity of the reservoir reference sites to the basin were influenced by the artificially high water table created by the dam and a full reservoir. Also, the number of hydrologic inputs and the shallow depth of some of the channels draining into the basin may allow a greater number of species to be present in the reservoir reference sites. Wright, Flecker, and Jones (2003) found that soil moisture had a significant effect on herbaceous plant communities in beaver meadows in the Adirondack Mountains in New York State, 
stating that in the first year of a two-year study, species richness was driven by water table depth and years since abandonment. Field surveys from Wright, Flecker, and Jones (2003) indicated that species richness increased through time in the abandoned ponds. They speculated that the increase in spatial heterogeneity of sediments over time, mainly soil moisture changes, could lead to the increase of species throughout the meadows.

However, the meadow location in my study predicts a decrease in species richness over time at the reservoir (Table 4). As noted, the reference areas are dominated by Carex sp., but Carex is rare in the reservoir; this is consistent with Sjoberg and Danell (1983) who examined the effect permanent flooding had on three previously temporarily flooded riparian meadows where Carex species were abundant. They found that after one year of inundation, Carex species shoot densities and standing crop decreased in two of the lakes and after three years Carex had been completely eliminated. Soil texture often plays a role in determining what species can occur at a particular location (Laughlin and Abella 2007), and may be playing a role at the reservoir reference site. Reservoir reference sites contain a higher silt and lower sand content on average than the meadow location, which could explain the higher species richness at the reservoir site. The slight increase in fine material near the reservoir combined with near constant saturation could be supporting more facultative wetland species when compared with meadow reference location (Boone-Kauffman et al. 1997).

Soil moisture levels of the Dream Lake basin are still quite high, ranging from 3584\%. As desiccation leads to more physically ripe sediments plant species richness will be influenced and community composition will change. The sudden shift in hydrology and continual drop in water table often plays the most important role in the variability of 
plant communities in permanently or seasonally flooded environments (Sjoberg and Danell 1983, Castelli, Chambers, and Tausch 2000). As soil moisture decreases in the dewatered areas and the historic pattern of temporary flooding returns, the dense mats of Carex species that characterize the reference areas may once again dominate the former reservoir.

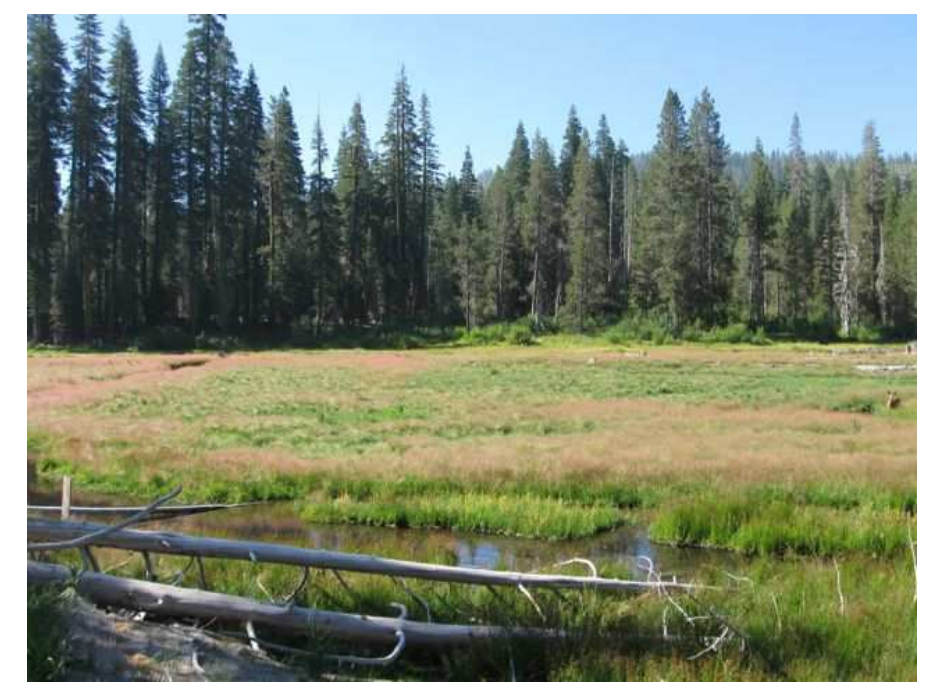

Fig. 7. Rapid revegetation of Dream Lake, August 2012.

Unlike studies conducted in Wisconsin that found plant communities in former reservoirs heavily favored invasive species (Lenhart 2000, Orr and Koenig 2006, Orr and Stanley 2006), most of the plants that I could positively identify at Dream Lake were native. Weedy and invasive species are quick to colonize disturbed areas with high nutrient content. Increased availability of nutrients in reservoirs is driven by the breakdown of organic material once it is exposed to air after drawdown. The relatively low organic matter content of the reservoir soil at Dream Lake could be excluding invasive weeds and favoring colonization by fast growing natives.

Upstream land use could also explain differences in plant communities between 
my study and the studies conducted in Wisconsin where invasive species were dominant. Dream Lake was a spring-fed reservoir, located within the boundary of a national park. The nearest developed area is the Drakesbad Guest Lodge, downstream and downhill from the former reservoir. Water that flowed into Dream Lake traveled a relatively short distance above ground and flowed through undisturbed natural meadows. Many of the dams in Wisconsin were on larger river systems that flowed near or through land that was impacted by human development. Therefore, upstream land use may have contributed to the invasive plant communities establishing in Wisconsin dam removal sites. Annual vegetation surveys and monitoring by the National Park Service would not only inform future dam removal projects, but also allow for quick identification and eradication of invasive plant populations that may establish in the future. Active monitoring would ensure that native populations continue to thrive in the former reservoir.

The Wisconsin studies have also reported high variability in plant communities through time, and so I expect that the plant community at Dream Lake will not be the same from year to year. Methods of seed dispersal play important roles in community composition of newly exposed mudflats. Wind and water dispersed species may have an advantage over plant species that rely on animals or other means of dispersal to establish in the exposed mudflats of former reservoirs. The unripe soils of newly exposed reservoirs may limit travel across the surface by animals that can help disperse seed. Through time and as soils ripen, different plant species may be introduced through a wider variety of dispersal methods changing floristic composition rapidly.

It has also been suggested that the time of year a dam is removed could have considerable impact on the trajectory of initial colonizers (Orr and Stanley 2006). Dream 
Lake was drained in August 2011, a time when spring and early-summer plants are setting seed. Native plants ready to release seed in late summer near Dream Lake could have taken advantage of the nutrient rich sediments and abundant soil moisture exposed by the draining of Dream Lake. As dams continue to come down, more data may become available regarding timing of reservoir dewatering and its impact on initial plant community establishment.

Texture and $\mathrm{pH}$ of soils are properties that also exhibit strong influences on plant community composition. Saturated, fine-textured soils in low gradient riparian zones will support sedges, rushes, and water-loving grasses (Boone-Kauffman et al. 1997). This is true of the reference plant community at Dream Lake, which is dominated by a facultative sedge community. The current average $\mathrm{pH}$ of sediment in the basin (5.4) indicates that nutrients are more readily available to the plants growing there and is more than likely contributing to the rapid plant growth and density in the reservoir. 


\section{CONCLUSIONS}

The aim of this paper was to investigate the response of soil and early vegetation establishment following removal of a small dam by comparing formerly inundated soils with undisturbed soil. My results indicate that after eighty years of inundation, organic material in the reservoir decreased, the soil is more alkaline, and reduced conditions exist. One year following dewatering, physical ripening of sediments was occurring, though it is in different stages throughout the reservoir. Chemical ripening has not yet occurred because it can only be initiated once physical ripening is complete. The oxidation of organic matter is occurring and providing nutrients to plants that have rapidly colonized the exposed mudflat. Investigations of the physical and chemical properties in reservoir sediments after dam removal are sparse, and few analogs exist with which to compare post-removal conditions. My results indicate that the physical and chemical properties of dewatered sediment will have a direct impact on the restoration process, which emphasizes the need for further research.

\section{Limitations}

An important limitation for this study was time. Observing the physical, chemical, and above ground biological changes for only one year following dam removal has provided a mere baseline for further research. The high variability in plant communities following disturbance has been well documented and mentioned throughout this paper. Additionally, previous studies mentioned here have also indicated that longterm monitoring of dam removal sites is imperative in order to reach more definitive conclusions on restoration trajectories. The duration of this assessment falls short of 
long-term, but my study does provide more data to build from for future work.

The second and third limitations of this study go hand in hand. The high percentages of organic material in my soil samples presented challenges to determining particle size. Also, the NPS allows for the collection of only one gallon of soil from a research site within a park. Therefore, the small amount of sample I had to work with in the lab required finding methods for determining particle size that could be conducted with five grams of soil or less. I initially attempted the micropipette method because it required only five grams of air-dried soil. However, the initial sand and silt withdraw was not successful because the organic matter in the solution prevented liquid from entering the pipette. I made several attempts to remedy the problem of high organic matter in the samples, but the small physical size of each collected composite limited the number of trial and error that could occur.

\section{Implications for Restoration}

There is a close relationship between vegetation and the several stages of soil ripening (Pons and Zonneveld 1965). There is no evidence to suggest that actively planting native species in drained reservoirs will ensure, or even promote, growth of native plant communities, or prevent establishment of invasive species. The best approach to the restoration of dewatered reservoir sediment could be a passive approach with monitoring. Passive restoration is simply the halting of anthropogenic activities that are degrading a system. The physical ripening of sediments begins with the initial draining of the reservoir. The timing of reservoir drawdown and lack of further disturbance through active restoration approaches may have influenced the positive 
outcome of native plant establishment throughout the basin.

If active restoration is required, quick-growing annual grasses, forbs, and herbaceous plants should be the first plants to be planted in the former reservoir. These plants can speed physical ripening by establishing root systems that will draw more water from sediment. The decreased physical ripening time allows for the planting of woody shrubs and trees more quickly after the reservoir has been drained. Recently dewatered sediments may take decades to physically and chemically ripen. Trees immediately planted in these sediments may not be well supported when they reach more mature ages because the unripe soil at depth cannot support their weight.

My results are not entirely consistent with other dam removal studies, and in the case of organic matter content, my results show a response opposite to all other studies. This reminds us that we have yet to approach a general theory on the ecological response to dam removal; we must continue to document the influence of geography, reservoir management, and pre-existing conditions on post-dam recovery in order to better understand the implications of this process.

Despite some limitations, this study and its results emphasize the need for thorough and long-term monitoring of dam removal projects. Dam removal restoration projects could reach more desirable outcomes and be less costly with an understanding of the physical and chemical ripening of reservoir sediments immediately following dam removal. If ecosystem function is a measure of ecological restoration, above and below ground conditions must be understood for a revegetation project to be successful. 
The ripening index offers an opportunity for managers to quickly and quantitatively assess edaphic changes following dam removal, perhaps influencing plant community trajectories to a more desired state. 


\section{WORKS CITED}

ASTM. 2007c. Standard Test Methods for Moisture, Ash, and Organic Matter of Peat and Other Organic Soil: D 2974-07a. West Conshohocken, PA: ASTM International.

Auble, G. T., P. B. Shafroth, M. L. Scott, and J. E. Roelle. 2007. Early vegetation development on an exposed reservoir: Implications for dam removal.

Environmental Management 39:806-618.

Bernhardt, E. S., M. A. Palmer, J. D. Allan, G. Alexander, K. Barnas, S. Brooks, J. Carr, S. Clayton, C. Dahm, J. Follstad-Shah, D. Galat, S. Gloss, P. Goodwin, D. Hart, B. Hassett, R. Jenkinson, S. Katz, G. M. Kondolf, P. S. Lake, R. Lave, J. L. Meyer, T. K. O’Donnell, L. Pagano, B. Powell, E. Sudduth. 2005. Synthesizing U. S. river restoration efforts. Science 308:636-637.

E. B. Sudduth, M. A. Palmer, J. D. Allan, J. L. Meyer, G. Alexander, J. FollstadShah, B. Hassett, R. Jenkinson, R. Lave, J. Rumps, and L. Pagano. 2007. Restoring rivers one reach at a time: Results from a survey of U. S. river restoration practitioners. Restoration Ecology 15:482-493.

Boone-Kauffman, J., R. L. Beschta, N. Otting, and D. Lytjen. 1997. An ecological perspective of riparian and stream restoration in the Western United States. Fisheries 22:12-24.

Brady, N. C., and R. R. Weil. 1999. The Nature and Properties of Soils, $12^{\text {th }}$ Edition. Upper Saddle River, NJ: Prentice Hall.

Brown, R. L., and J. Chenoweth. 2008. The effect of Glines Canyon Dam on hydrochorous seed dispersal in the Elwha River. Northwest Science 82:197-209.

Burt, R. 2004. Soil Survey Laboratory Methods Manual, Version 4.0. Lincoln, Nebraska: Natural Resources Conservation Service.

Butler, D. R., and G. P. Malanson. 1995. Sedimentation rates and patterns in beaver ponds in a mountain environment. Geomorphology 13:255-269.

Castelli, R. M., J. C. Chambers, and R. J. Tausch. 2000. Soil-plant relations along a soil water gradient in Great Basin riparian meadows. Wetlands 20:251-266.

Cook, K. L., W. W. Wallender, C. S. Bledsoe, G. Pasternack, and S. K. Upadhyaya. 2011. Effects of native plant species, mycorrhizal inoculum, and mulch on restoration of reservoir sediment following dam removal, Elwha River, Olympic Peninsula, Washington. Restoration Ecology 19:251-260.

Daubenmire, R. F. 1959. A canopy-coverage method. Northwest Science 33:43-64. 
Doyle, M. W., E. H. Stanley, and J. M. Harbor. 2002. Geomorphic analogies for assessing probably channel response to dam removal. Journal of the American Water Resources Association 38:1567-1579.

— J. M. Harbor. 2003. A scaling approximation of equilibrium time-scales for sand-bed and gravel-bed rivers responding to base-level lowering. Geomorphology 54:217-223.

, E. H. Stanley, C. H. Orr, A. R. Selle, S. A. Sethi, and J. M. Harbor. 2005. Stream ecosystem response to small dam removal: Lessons from the Heartland. Geomorphology 71:227-244.

Drexler, J. Z., C. S. de Fontaine, and S. J. Deverel. 2009. The legacy of wetland drainage on the peat resource in the Sacramento - San Joaquin Delta, CA, USA. Wetlands 52:129-147.

Duda, J. J., J. E. Freilich, and E. G. Schreiner. 2008. Baseline studies in the Elwha River ecosystem prior to dam removal: Introduction to the special issue. Northwest Science 82:1-12.

Gee, G. W., and D. Or. 2002. Particle-Size Analysis. In Methods of Soil Analysis. Part 4. Physical Methods. J. H. Dane and G. C. Topp (eds.), 255-293. Soil Science Society of America: Madison, WI.

Hay, K. G. 2010. Succession of beaver ponds in Colorado 50 years after beaver removal. Journal of Wildlife Management 74:1732-1736.

Hoke A, L. Warner, C. Gilbert, and K. Koch. 2005. Cultural landscape report for Drakesbad Guest Ranch, Lassen Volcanic National Park. Mineral (CA): USDI National Park Service, Pacific West Region.

Johnson L, S. Eagan, N. Malone, D. Rosenblatt, E. Higbee, K. Conti, P. Hudson, J. Hutchinson, M. Lowe, and K. Maeyama. 2009. Warner Valley Comprehensive Site Plan: Draft Environmental Impact Statement. Mineral (CA): USDI National Park Service, Lassen Volcanic National Park.

Kim, D. J., J. Feyen, H. Vereecken, D. Boels, and J. J. B. Bronswijk. 1993. Quantification of physical ripening in an unripe marine clay soil. Geoderma 58:67-77.

Lafrenz, M. D., R. A. Bean, and D. Uthman. In press. Soil ripening following dam removal. Physical Geography. 
Laughlin, D. C., and S. R. Abella. 2007. Abiotic and biotic factors explain independent gradients of plant community composition in ponderosa pine forests. Ecological Modelling 205:231-240.

Lenhart, C. 2000. The vegetation and hydrology of impoundments after dam removal in Southern Wisconsin. MS Thesis, University of Wisconsin - Madison.

Machtinger, E. T. 2007. Temporarily flooded wetlands. Washington, DC: United States Department of Agriculture, Natural Resources Conservation Service.

McBride, M. B. 1994. Environmental Chemistry of Soils. New York, NY: Oxford University Press.

Michel, J. T., J. M. Helfield, and D. V. Hooper. 2011. Seed rain and revegetation of exposed substrates following dam removal on the Elwha River. Northwest Science 85:15-29.

National Research Council. 1992. Restoration of Aquatic Ecosystems. Washington, DC: National Academy Press.

Neff, D. J. 1957. Ecological effects of beaver habitat abandonment in the Colorado Rockies. The Journal of Wildlife Management 21:80-84.

Orr, C. H., and E. H. Stanley. 2006. Vegetation development and restoration potential of drained reservoirs following dam removal in Wisconsin. River Research and Applications 22:281-295.

, and S. Koenig. 2006. Planting and vegetation recovery on exposed mud flats following two dam removals in Wisconsin. Ecological Restoration 24:79-86.

— , K. L. Rogers, and E. H. Stanley. 2006. Channel Morphology and P uptake following removal of a small dam. Journal of the North American Benthological Society 25:556-568.

Pess, G. R., M. L. McHenry, T. J. Beechie, and J. Davies. 2008. Biological impacts of the Elwha River Dams and potential salmonid responses to dam removal. Northwest Science 82(sp1): 72-90.

Pohl, M. M. 2002. Bringing down our dams: Trends in American dam removal rationales. Journal of the American Water Resources Association 38:1511-1519.

Pons, L. J., and I. S. Zonneveld. 1965. Soil Ripening and Soil Classification: Initial Soil Formation in Alluvial Deposits and a Classification of the Resulting Soils, Publication 13. Wageningen, Netherlands: International Institute for Land Reclamation and Improvement. 
Segini, A., A. Posadas, R. Quiroz, D. Marcondes Bastos Pereira Milori, S. C. Saab, L. M. Neto, and C. Manoel Pedro Vaz. 2010. Spectroscopic assessment of soil organic matter in wetlands from the High Andes. Soil Science Society of America Journal 74:2246-2253.

Shafroth, P. B., J. M. Friedman, G. T. Auble, M. L. Scott, and J. H. Braatne. 2002. Potential responses of riparian vegetation to dam removal. BioScience 52:703712.

Sjoberg, K., and K. Danell. 1983. Effects of permanent flooding on Carex-Equisetum wetlands in Northern Sweden. Aquatic Botany 15:275-286.

Snyder, N. P., D. M. Rubin, C. N. Alpers, J. R. Childs, J. A. Curtis, L. E. Flint, and S. A. Wright. 2004. Estimating accumulation rates and physical properties of sediment behind a dam: Englebright Lake, Yuba River, northern California. Water Resources Research 40(W11301):1-19.

Society for Ecological Restoration International Science and Policy Working Group. 2004. The SER International Primer on Ecological Restoration. www.ser.org \& Tucson: Society for Ecological Restoration International.

Soil Survey Staff. 1999. Soil Taxonomy, $2^{\text {nd }}$ Edition. Washington, DC: USDA Natural Resources Conservation Service.

Stanley, E. H., M. A. Luebke, M. W. Doyle, and D. W. Marshall. 2002. Short-term changes in channel form and macroinvertebrate communities following low-head dam removal. Journal of the North American Benthological Society 21:172-187.

— Frontiers in Ecology and the Environment 1:15-22.

U.S. Army Corps of Engineers (USACE). "National Inventory of Dams.” Accessed 18 May 2013, http://geo.usace.army.mil/pgis/f?p=397:12:.

U.S. Department of Agriculture, Natural Resources Conservation Service (NRCS). "Web Soil Survey." Last modified 17 February 2012, http://websoilsurvey.nrcs.usda.gov/app/HomePage.htm

U.S. National Oceanic and Atmospheric Administration, National Climatic Data Center (NCDC). Accessed 18 May 2013, http://www.ncdc.noaa.gov/.

Vermeulen, J., T. Grotenhuis, J. Joziasse, and W. Rulkens. 2003. Ripening of clayey dredged sediments during temporary upland disposal: A bioremediation technique. Journal of Soils and Sediments 3:49-59. 
, S. G. van Dijk, J. T. C. Grotenhuis, and W. H. Rulkens. 2005. Quantification of physical properties of dredged sediments during physical ripening. Geoderma 129:147-166.

Vepraskas, M. J., and S. P. Faulkner. 2001. Redox chemistry of hydric soils. In Wetland Soils, J. L. Richardson and M. J. Vepraskas (eds.), 85-105. CRC Press, New York, NY.

Wells, A. J., N. J. Balster, S. VanWychen, and J. Harrington. 2008. Differences in belowground heterogeneity within a restoration of a dewatered reservoir in southwestern Wisconsin. Restoration Ecology 16:678-688.

Wisconsin Department of Natural Resources (WDNR). "Dam Safety." dnr.wi.gov. Last modified 18 February 2013. http://dnr.wi.gov/topic/Dams/.

Wright, J. P., A. S. Flecker, and C. G. Jones. 2003. Local vs. landscape controls on plant species richness in beaver meadows. Ecology 84:3162-3173. 